
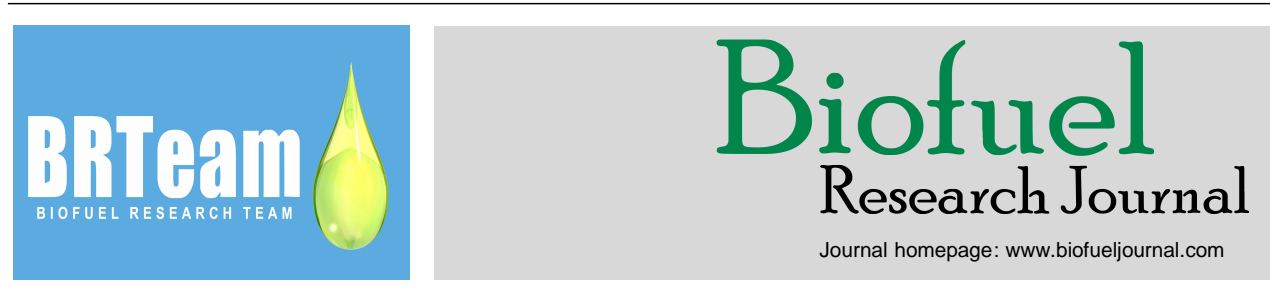

Review Paper

\title{
Modern microbial solid state fermentation technology for future biorefineries for the production of added-value products
}

\author{
Musaalbakri Abdul Manan ${ }^{1,2}$, Colin Webb ${ }^{2, *}$
}

${ }^{I}$ Enzyme and Fermentation Technology Programme, Biotechnology and Nanotechnology Research Centre, Malaysian Agricultural Research and Development Institute (MARDI), Persiaran MARDI - UPM, 43400 Serdang, Selangor Malaysia.

${ }^{2}$ School of Chemical Engineering and Analytical Science, The University of Manchester, Oxford Road, Manchester M13 9PL, United Kingdom.

\section{HIGHLIGHTS}

$>$ Novel biorefinery processes using solid state fermentation technology (SSF) was reviewed and discussed.

$>$ Future biorefineries based on SSF serve as ideal platforms for the production of added-value products.

$>$ Generic fermentation feedstocks provide a

complete nutrient for subsequent microbial

fermentations.

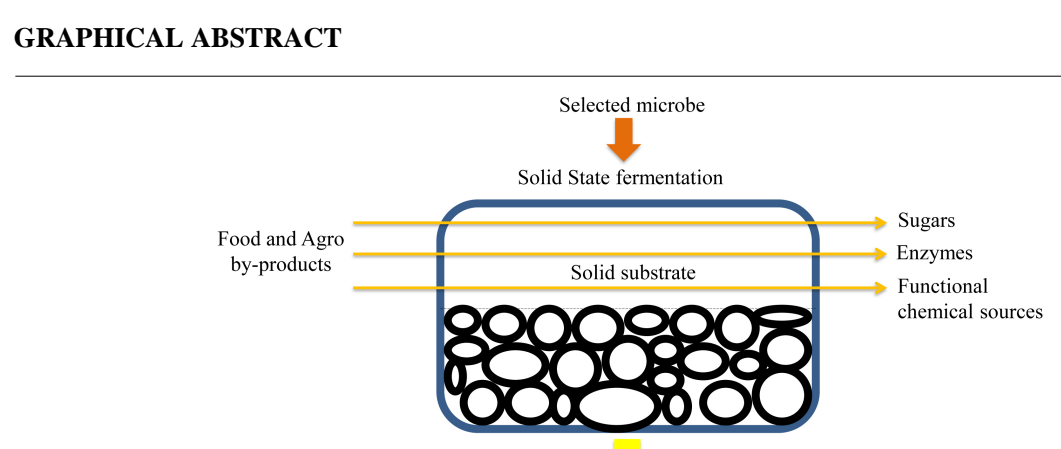

Generic fermentation feedstocks

Selected microbes

Value added products:

Biodegradable plastics, Fuel, Chemicals, etc.

\section{ARTICLE INFO}

\section{Article history:}

Received 29 August 2017

Received in revised form 15 October 2017

Accepted 15 October 2017

Available online 1 December 2017

\section{Keywords:}

Solid state fermentation

Biorefineries

Microbial bioconversion

Submerged fermentation

Added value products

\begin{abstract}
The promise of industrial biotechnology has been around since Chaim Weizmann developed acetone-butanol-ethanol fermentation at the University of Manchester in 1917 and the prospects nowadays look brighter than ever. Today's biorefinery technologies would be almost unthinkable without biotechnology. This is a growing trend and biorefineries have also increased in importance in agriculture and the food industry. Novel biorefinery processes using solid state fermentation (SSF) technology have been developed as alternative to conventional processing routes, leading to the production of added-value products from agriculture and food industry raw materials. SSF involves the growth of microorganisms on moist solid substrate in the absence of free-flowing water. Future biorefineries based on SSF aim to exploit the vast complexity of the technology to modify biomass produced by agriculture and the food industry for valuable by-products through microbial bioconversion. In this review, a summary has been made of the attempts at using modern microbial SSF technology for future biorefineries for the production of many added-value products ranging from feedstock for the fermentation process and biodegradable plastics to fuels and chemicals.
\end{abstract}

(C) 2017 BRTeam. All rights reserved.

\footnotetext{
* Corresponding author at: Tel.: +44 1613064379
}

E-mail address: colin.webb@manchester.ac.uk

Please cite this article as: Abdul Manan M., Webb C. Modern microbial solid state fermentation technology for future biorefineries for the production of added-value products. Biofuel Research Journal 16 (2017) 730-740. DOI: 10.18331/BRJ2017.4.4.5 


\section{Contents}

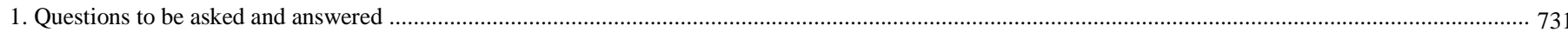

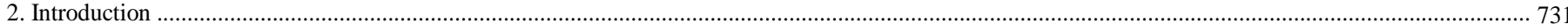

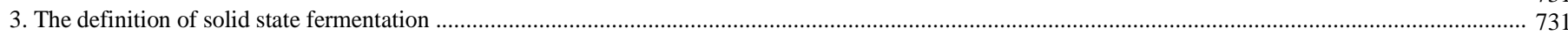

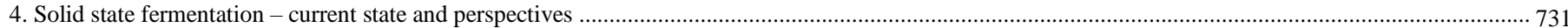

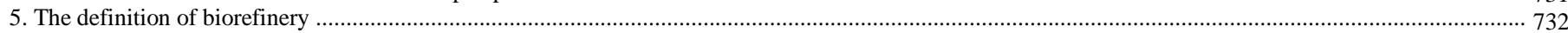

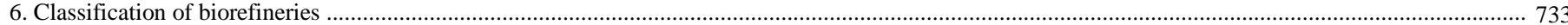

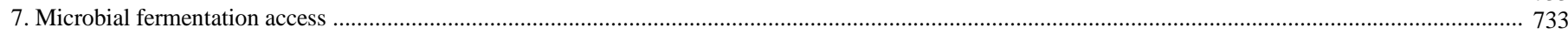

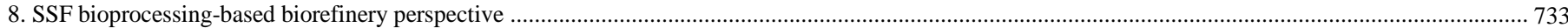

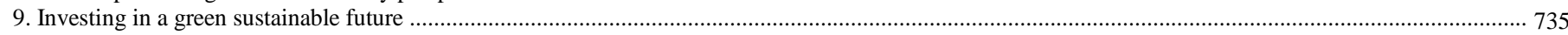

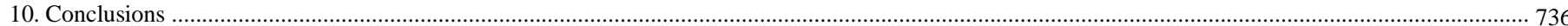

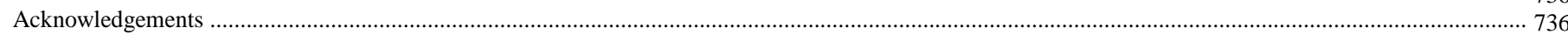

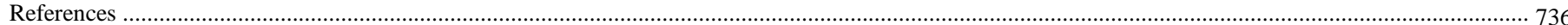

\section{Questions to be asked and answered}

Can we imagine our land full of solid waste materials either from industry, agriculture or households for the next 20 years? What happens if people keep throwing things onto the land without thinking of any consequences in the future? What role can be played by scientists to overcome this matter? Do you believe we can turn this waste into something valuable and keep a healthy environment? Did you know we can use tiny microorganisms to do a job for us in processes to overcome these problems especially when dealing with waste produced from food and agro-industry? But one thing we should know is that waste solids will remain in the waste stream and require expensive disposal or treatments.

\section{Introduction}

There is a strong need to produce new products (food and non-food, chemicals) from food and agro-industrial residues in a more sustainable way than are currently realized or possible. Sustainable production is defined here as production that is efficient and effective in the use of raw materials and energy, generates a minimum of waste or low-value streams, and leads to new and existing products and/or materials with the required functionality, safety and integrity. Solid state fermentation (SSF) and related technologies offer alternative production routes for such biotechnology-based products.

SSF has been used in the world for a long time. This technology is commonly known in the East, for traditional manufacture of fermented foods, and in the West, for mould-ripened cheese. It can be defined as a system in which the growth of selected microorganism(s) occurs on solid materials with a low moisture content and has been identified as a potentially important methodology and technique in biotechnology. Nowadays, SSF is an economically viable, practically acceptable technology for large-scale microbial bioconversion and biodegradation processes. Development of sustainable SSF and bioprocess technology is an emerging, multidisciplinary field with possible application to the production of food, enzymes, animal feed, chemicals, cosmeceutical products, bioethanol and pharmaceuticals/ nutraceuticals. During recent years, SSF has received fresh attention from researchers and industries all over the world. This is due to several major advantages that it offers over submerged fermentation $(\mathrm{SmF})$, particularly in the area of solid waste treatment. Apart from the production of food and feed, SSF shows tremendous potential in applications to produce high-value lowvolume products such as enzymes, biologically active secondary metabolites, and chemicals. SSF offers many advantages over conventional SmF such as simple and inexpensive substrates, elimination of the need for solubilization of nutrients from within solid substrates, elimination of the need for rigorous control of many parameters during fermentation, mostly higher product yields, lower energy requirements, less waste water produced, no foam generation, and relatively easy recovery of end products. SSF provides flexibility in terms of the raw materials to be used and their capability to produce various value-added products by microbial bioconversion. Thus, modern SSF holds the highest potential for biorefinery targets for the production of many value-added products.

\section{The definition of solid state fermentation}

Over the last four decades, various terms have been used as synonyms of SSF. The most popular term is "solid state fermentation" itself, but terms such as "solid substrate fermentation", "solid state bioprocessing", "solid substrate cultivation", "solid substrate process", "solid state digestion", "solid state cultivation", "solid state culture", "surface cultivation", and "surface culture" have also been used to describe the same process. The term "solid state fermentation" is the most commonly used term followed by "solid substrate fermentation". Later, Botella et al. (2009) introduced a new term "particulate bioprocessing", a novel process strategy developed for biorefineries based on SSF. In this case, they described particulate bioprocessing as confined to those systems that involve the growth of microorganisms on moist solid materials in a particulate state. Amore and Faraco (2012) introduced the the term consolidated bioprocessing (CBP) as the main route for lignocellulosic degradation that makes fungi alternative and better candidates. Here, they introduced cellulolytic fungi as candidates with great potential to provide saccharolytic enzymes to digest lignocellulose efficiently and produce sugars, then later convert those sugars to ethanol. The proposed activities provide an important contribution to reducing ethanol production cost and showing that the fungi naturally possess all pathways required for the conversion of lignocellulose to bioethanol.

SSF has been defined in many ways. Many researchers in the field have introduced their own ways to define SSF. For example, Viniegra-Gonzalez (1997) defined SSF as a microbial process occurring mostly on the surface of solid materials that have the property to absorb or contain water, with or without soluble nutrients. Mitchell et al. (2000) described SSF as any processes in which substrates in a solid particulate state are utilised, while Pandey et al. (2000) defined SSF as the cultivation of microorganisms on moist solid supports, either on inert carriers or on insoluble substrates that can also be used as carbon and energy source. Rahardjo et al. (2006) in their review article, came out with a definition that SSF is the growth of microorganisms on moistened solid substrate, in which enough moisture is present to maintain microbial growth and metabolism, but where there is no free-moving water and air is the continuous phase. Rosales et al. (2007) gave a simple definition of SSF where the growth of microorganisms is on solid or semisolid substrates or support. Later, Mitchell et al. (2011) defined SSF as a process that involves the growth of microorganisms on moist particles of solid materials in beds in which the spaces between the particles are filled with a continuous gas phase. In the latest definition, Thomas et al (2013) defined SSF as a three-phase, heterogeneous process, comprising solid, liquid, and gaseous phases, which offers potential benefits for the microbial cultivation for bioprocess and products development. Whatever the definition, we can understand that SSF is referring to the microbial fermentation, which takes place in the absence or near absence of free water, thus being close to the natural environment to which the selected microorganisms, especially fungi, are naturally adapted.

\section{Solid state fermentation - current state and perspectives}

Examining publications during the past decades reveals the principal authors in the field of SSF. Names such as Pandey, Soccol, Szakacs, Freire, Gomes, Mitchell, and Rinzema appear to be the most active scientists involved in SSF research. India proved to be the most active country based on the number of publications followed by Brazil and China. This is likely to be because both food and agro-industry waste is produced in huge amounts in these countries. Considerable research activity is also evident in the USA, Mexico, Spain, France, Japan, the UK, and the Netherlands. 
Industrial practice in SSF for secondary metabolite production has been led by companies such as Biocon Ltd. Biocon India developed technology based on SSF as a low-cost, low-energy option for the production of specialty enzymes. The company started as early as 1990 on an 8-year research and development program to create a novel bioreactor capable of conducting SSF with comparable levels of automation and specialization as those associated with SmF (Suryanarayan, 2003). The founder Kiran Mazumdar Shaw started the biotechnology company at the age of 25 in Bangalore, India. In 2009, Biocon Ltd. was named by Forbes in the "best under a billion" company list and Shaw herself as worth about $£ 560$ million (Stylist, 2011).

Cristobal et al. (2008) mentioned that the great success of SSF is not only related to the notable increase in research in this area, but also to significant industrial developments especially in enzyme production. The last two decades witnessed an unprecedented increase in interest in SSF. There has been a concerted effort to understand the issues involved in SSF and to apply them to a wide range of new products. The majority of publications are about the use of microbial fermentation and the possibility of utilizing different solid waste products as raw material. Through SSF, solid waste either from food or agroindustry can be used as commercially desirable substrates (Hanc and Dreslova, 2016).

Many research works have so far focused on the general applicability of SSF for the production of enzymes, metabolites, and spores. Food and agro-industry provide many different solid waste products suitable as valuable solid substrates, which have been combined with many different microorganisms and resulted in a wide range of fermentation processes. For example, enzyme production by SSF is a growing field due to the simplicity of the processes, high productivity, and generation of concentrated products (Panesar et al., 2016). Another important factor that influences the development of SSF is that both food and agro-industrial waste is rich in carbohydrates and other nutrients so that it can serve as a substrate for the production of bulk chemicals and enzymes (Saithi and Tongta, 2016). In addition, SSF is a good alternative to help in solving pollution problems, rather than disposing of waste into the land and causing environmental harm. Research studies on microbial growth in SSF are limited compared to those in SmF. The majority of published research focuses on the optimization of environmental conditions to achieve maximum production and substrate utilization rates (Behera and Ray, 2016). With the advances of biotechnology and bioprocessing nowadays, for example in the area of enzyme and fermentation technology, many new avenues have opened for their utilization in SSF (El-Bakry et al., 2015).

Growth and product formation kinetics, bioreactor design, and process control in SSF are becoming popular research subjects. With the increased interest in SSF, progress is being made nowadays with the goal of developing industrially applicable SSF systems. Research on kinetic studies has become one of the most popular and critical subjects to be explored, and with developments in computer and software technology, such studies have become easier. The prediction of microbial growth and product formation could be achieved with simulations and parameter estimation if we had a better understanding of how microorganisms grow and produce the desired products in SSF. Accurate modeling and determination of process variables in SSF such as moisture, temperature (Hamidi-Esfahani et al., 2004; Dalsenter et al., 2005; Fanaei and Vaziri, 2009), pH (Jiang et al., 2012), color changes (Abdul Manan and Webb, 2016), biomass determination by oxygen uptake rate (JimenezPenalver et al., 2016), carbon dioxide production rate (Farinas et al., 2011), glucosamine (Patil and Jadhav, 2014), fungal growth and enzyme production (Hamidi-Esfahani et al., 2007; De la Cruz-Quiroz et al., 2017) related to kinetic studies, and modeling for optimization of SSF have been investigated extensively.

Bioreactor design for SSF has been studied extensively and is another important area for development (Khanahmadi et al., 2006). Developments during the past 15 years suggest that there is now considerable interest in studying various aspects of SSF bioreactor design. Bioreactors such as packed beds (Khanahmadi et al., 2006; Fanaei and Vaziri, 2009; Melikoglu et al., 2015; Dias et al., 2017; Finkler et al., 2017; Poletto et al., 2017), multi-layer packed beds (Shojaosadati and Babaeipour, 2002; Pitol et al., 2016), rotating drums bioreactor (Saithi and Tongta, 2016; Poletto et al., 2017), column bioreactors (Linde et al., 2007; Salum et al., 2010), column-tray bioreactor (Ruiz et al., 2012), magnetic rotating biological contactors (Saha and Takashi, 1997), fixed beds (Cavalcanti et al., 2005), immersion bioreactors (Saithi and Tongta, 2016), tray systems (Khanahmadi et al., 2004; Bhanja et al., 2007), horizontal stirred tanks (Gregori et al., 2016) and other bioreactors (Takashi et al., 2009) have been reported.

The biotransformation and biological upgrading of food and agroindustry waste for improved nutritional qualities can be achieved through SSF technology (Biz et al., 2016). This has been the most important area where the potential of SSF has been recognized to offer economically feasible technology and provide the possibility of a continuous operation for new value added products (Cerda et al., 2016). Various high-value biotechnological products such as enzymes, primary and secondary metabolites, antibiotics, and chemicals can be produced through SSF because it uses cheap solid substrates which are available locally and are rich in carbohydrates and other nutrients (Postemsky et al., 2017). In the case of wheat bran, research has been developed for its utilization as an SSF substrate for added-value products. As examples, the production of the antifungal antibiotic iturin (Shih et al., 2008; Takashi et al., 2009), nigerloxin (Chakradhar et al., 2009), meroparamycin (El-Naggar et al., 2009), $\gamma$-aminobutyric acid (GABA) (Dikshit and Tallapragada, 2015), antioxidants, monacolin $\mathrm{K}$ and biopigments (Pengnoi et al., 2017), clavulanic acid (Wang and Chen, 2016), lovastatin (Raghunath et al., 2012), gallic acid (Mata-Gomez et al., 2015), L (+) lactic acid (Naveena et al., 2005) and bioactive phenolic compounds (Dey and Kuhad, 2014) have been reported.

Many published research articles refer to the advantages of SSF in enzyme production. These advantages include higher enzyme titers (Sandhya et al., 2005; Patil and Dayanand, 2006; Tellez-Jurado et al., 2006; Colla et al., 2010; Yoon et al., 2014; Doriya et al., 2016), higher productivity levels (Mrudula and Murugammal, 2001; Nagel et al., 2001a and b; Castilho et al., 2009; Saqib et al., 2010), stability of excreted enzymes (Diaz et al., 2006; Wolski et al., 2009; Colla et al., 2015), a low level of catabolic repression (Azeredo et al., 2007; Castilho et al., 2009; Hashemi et al., 2013; Ertan et al., 2014; Colla et al., 2015), and short fermentation time (Castilho et al., 2009; Ertan et al., 2014; Zhang et al., 2015; Kumar et al., 2016). Production of enzymes can be stimulated by a high sugar concentration in SSF but in SmF, such high concentrations have an inhibitory effect because of catabolic repression (Nair et al., 2008; Saqib et al., 2010; Hashemi et al., 2013; Colla et al., 2015; Hansen et al., 2015). SSF appears to be more robust than $\mathrm{SmF}$ with regard to catabolic repression and can therefore, be more productive with a wider variety of substrate mixtures (Nagel et al., 2001b; Zhang et al., 2015). According to Castilho e al. (2000), SSF has many advantages over SmF for lipase production by Penicillium candidum when it is grown on wheat bran substrate. The SSF process is very attractive from an economic point of view as well (Cerda et al., 2016; Gregori et al., 2016; Postemsky et al., 2017). Studies on economic analysis of lipase production showed that total capital investment needed for SmF was $78 \%$ higher than that needed for the SSF process (Castilho et al., 2000).

Thus, there has been much development of SSF in various biotechnology applications and in product development. The last two decades have changed the perception of SSF as "low technology" and it is becoming a promising technology for the production of added-value, "low volume and high cost" products. The majority of publications indicate that filamentous fungi are the most suitable organisms for growing under SSF conditions.

\section{The definition of biorefinery}

International Energy Agency (IEA) Bioenergy Task 42 has developed the definition of biorefinery as the sustainable processing of biomass into a spectrum of marketable products (food, feed, materials, chemicals) and energy (fuels, power, heat) (Sonnenberg et al., 2009; de Jong and Jungmeier, 2015). The National Renewable Energy Laboratory (NREL) defined a biorefinery as a facility that integrates biomass conversion processes and equipment to produce fuels, power, and chemicals from biomass (Berntsson et al., 2012). A biorefinery can use all kinds of biomass that can be upgraded to one or more valuable products such as agricultural by-products (wheat bran, rapeseed meal, straw, corn stover, bagasse), waste from the food industry (including kitchen and household waste), grains/cereals (wheat, maize, corn, soybean), starch and sugars, aquatic biomass (algae and seaweeds), as well as wood and lignocellulosic materials. A biorefinery is not a completely new concept. According to Berntsson et al. (2012), the term "biorefinery" became visible in the 1990s 
in response to at least four industry trends. First, there was a growing awareness in the industry to use biomass resources sustainably for economic and environmental sustainability. Second, there was an increase in interest in upgrading low-quality lignocellulosic biomass into highly valuable products. Third, there was a concern in starch production for energy applications. Finally, there was a need to develop high value-added products to face global competition by adopting the biomass produced from industry. Biorefineries can provide a significant contribution to sustainable development, generating added value to sustainable biomass use, and producing a range of bio-based products (food, feed, materials, chemicals) and bioenergy (fuels, power, and/or heat) at the same time (de Jong and Jungmeier, 2015).

\section{Classification of biorefineries}

In the past, biorefineries were classified based on a variety of different bases (de Jong and Jungmeier, 2015), such as:

I. Technological implementation status: conventional and advanced biorefineries; first, second, and third generation biorefineries.

II. Type of raw materials used: whole crop biorefineries, oleochemical biorefineries, lignocellulosic feedstock biorefineries, green biorefineries, and marine biorefineries.

III. Type of main intermediates produced: syngas platform biorefineries and sugar platform biorefineries.

IV. Main type of conversion process applied: thermochemical biorefineries, biochemical biorefineries, and two-platform concept biorefineries.

However, according to Lange (2017), biorefineries can be classified into six categories based on the availability of biomass:

I. The yellow biorefinery: straw, corn stover, wood.

II. The green biorefinery: fresh green biomass, grass for protein-rich feed.

III. The blue biorefinery: fish by-catch/cut-offs, fish discards and innards, mussels as biomass, brown seaweed, red and green algae, invertebrates such as sea cucumber.

IV. The red biorefinery: slaughterhouse waste identified as a new resource for upgrade to higher value products, for example food ingredients.

V. The white biorefinery: agro-industry side streams.

VI. The brown biorefinery: sludge and household waste.

\section{Microbial fermentation access}

A wide range of substrates is used for SSF. These include waste products from the agricultural and food industries. There is a need to decrease food and agro-industry processing waste because of environmental and economic problems (Farinas, 2015). Instead, better use of raw materials and more efficient processing of food and agro-industry solid materials into added-value products is needed (Stabnikova et al., 2010). Nowadays, scientists are using SSF to develop new process strategies for biorefineries. SSF bioprocessing in a biorefinery concept offers the versatile possibility to convert the sugarcontaining polymers starch, cellulose and hemicellulose into a range of products. Currently, commercially viable SSF processes involve solid substrates for producing products ranging from biofuels, bioethanol, biomethanol, biogas, and biodegradable plastics to commodity, platform, and specialty chemicals like succinic acid and pharmaceutical products. This is achieved by microbial bioconversions or enzymatic biotransformation (Koutinas et al., 2007a). Using food and agro-industry solid materials provides almost complete nutrient sources (Koutinas et al., 2007b). This is an advantage because during fermentation, solid materials can be used with/without supplementation.

Processes using microorganisms are very efficient and can be controlled (Saithi and Tongta, 2016). Another advantage is that the microorganisms act as specific catalysts that can produce a range of targeted products. An example includes using the fungus Aspergillus niger in the bioconversion of apple pomace into a multi-enzyme bio-feed (Zhong-Tao, 2009). Another example is making use of agro-industry waste (coconut husks, apple pomace, orange and lemon peel) as these materials can be used as inert carriers in SSF and allows good microorganism growth (Orzua et al., 2009). As found by many researchers globally, solid materials from food and agro-industry waste can be used as feedstocks for fermentation processes. They can be applied to biological activities such as producing various enzymes, animal feed, food ingredients, primary and secondary metabolites or nutraceutical, and pharmaceutical products.

Emerging technologies have high potentials because of their application in producing non-food materials. Examples include bioethanol and biofuels produced by food (Mahro and Timm, 2007) and agro-industry waste (Kim and Dale, 2004; Fatma and Fadel, 2010), biopulping (Chen et al., 2002 Giles et al., 2011), biological control (bioinsecticides) (Nalini and Parthasarathi, 2014; Shen et al., 2016), biodegradable plastic (poly (3hydroxybutyrate): PHB) (Ramadas et al., 2009; Xu et al., 2010), the production of functional chemicals (Koutinas et al., 2007a; Tokiwa and Calabia, 2008), and also production of feedstock for sequel fermentation processes (Koutinas et al., 2010). Koutinas et al. (2004) and Webb et al. (2005) proposed a novel cost-competitive wheat-based biorefining strategy for the production of nutrient-complete feedstock for microbial fermentation (Fig. 1). This upstream processing strategy exploits (1) the hydrolytic capability of fungi and (2) the natural autolysis of fungi to produce two liquid streams. Strategy (1) produced wheat hydrolysate rich in the glucose form. Strategy (2) produced fungal autolysate rich in supplementing nutrients, especially the nitrogen form (Koutinas et al. 2005). These strategies compensate for the most suitable carbon and nitrogen ratio for the subsequent submerged microbial fermentation process. Through this study, they proved the utilization of various microbial feedstocks produced from wheat via the proposed biorefinery for the production of PHB and succinic acid. It is desirable to use food and agroindustry waste solids as a renewable resource for sustainable chemical and non-chemical production through microbial bioconversions.

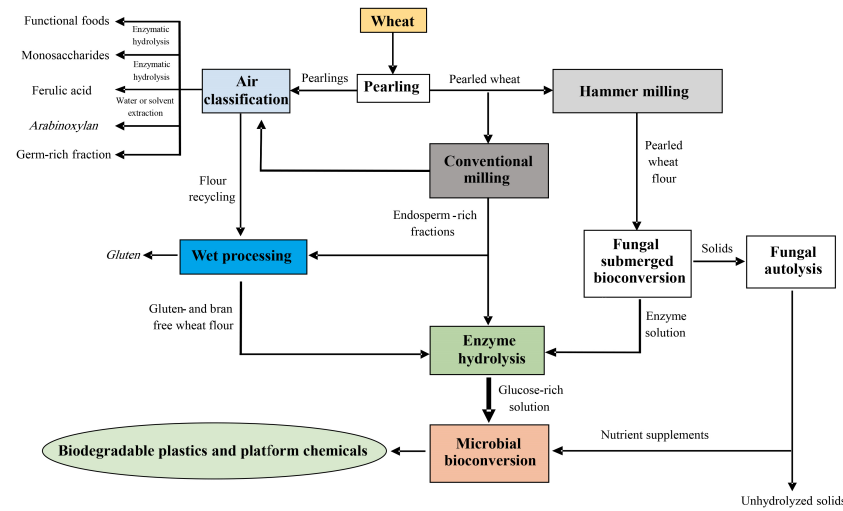

Fig.1. Schematic diagram of microbial fermentations proposed in a possible biorefinery utilizing wheat for the production of PHB and succinic acid. Adapted from Koutinas et al. (2004) and Webb et al. (2005).

\section{SSF bioprocessing-based biorefinery perspective}

Biomass from food and agro-industry (through microbial bioconversion or for the production of more added-value products) has helped in creating more viable biorefineries based on SSF. Generating a generic fermentation feedstock through fungal SSF provides the possibility of using residual solid waste from food and agro-industry. Successful research demonstrated that two filamentous fungi, one producing amylolytic enzymes (Aspergillus awamori) and the other producing proteolytic enzymes (Aspergillus oryzae), were both able to grow on various waste solids. Research focusing on the production of hydrolytic enzymes from a small portion of waste bread through SSF, and subsequent use of the enzymes to hydrolyze the remaining portion for the production of a nutrient-rich hydrolysate, was carried out by Melikoglu et al. (2013a) and Melikoglu (2008) (Fig. 2). As a result of the process, the nutrient-rich hydrolysate taken from both fermented substrates (containing carbon and nitrogen sources) was then used to support growth of a range of microorganisms including yeast and bacteria. Later, as extension from the project, Melikoglu et al. (2013b) produced a hydrolytic multi-enzyme solution that can be used for the production of a monomer rich hydrolysate from other segment of waste bread. Further, the nutrient rich hydrolysate can be converted into bioethanol or any other potential value-added products using selected microorganisms as shown in Figure 3. 


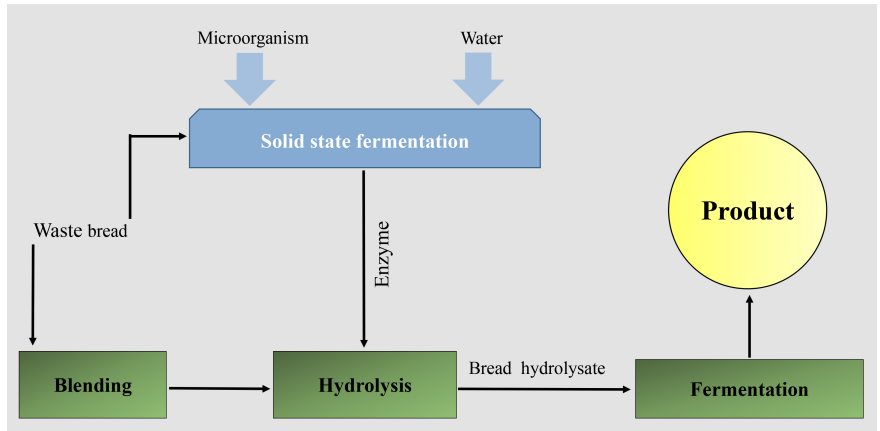

Fig.2. Schematic presentation of a novel bioprocess for the utilization of waste bread based on multi-enzyme-producing SSF. Adapted from Melikoglu et al. (2013a) and Melikoglu (2008).

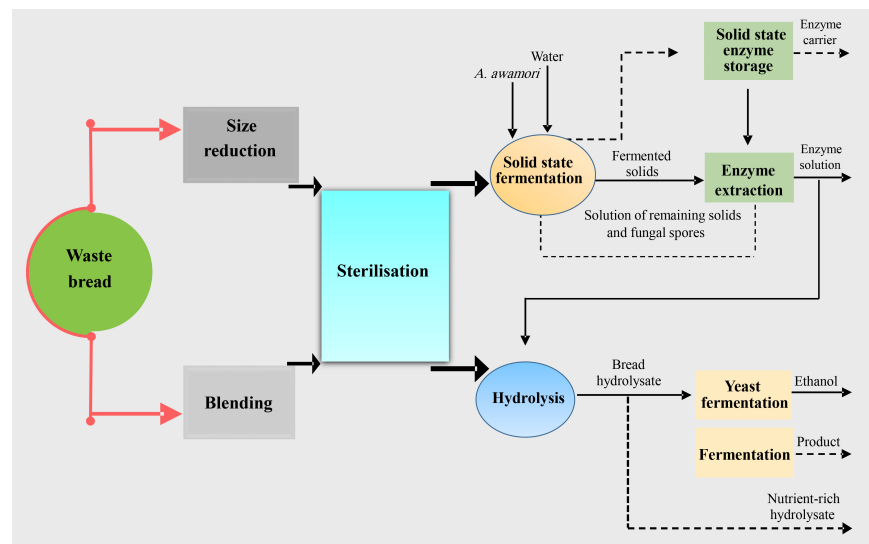

Fig.3. Proposed bioprocess for the production of bioethanol and other potential value-added products from waste bread by A. awamori in SSF. Dotted lines indicate optional steps in the process. Adapted from Melikoglu et al. (2013b).

Within their continuous studies, Du et al. (2008) also applied an SSF of $A$. awamori and A. oryzae on wheat bran to produce amylolytic-rich and proteolytic-rich solutions for efficient hydrolysis of wheat starch and protein. This produced glucose-rich and nitrogen-rich streams. In the following year, a wheat bran fraction was used as the only solid medium in two SSF processes of A. awamori and A. oryzae that produced enzyme complexes rich in amylolytic and proteolytic enzymes, respectively (Dorado et al., 2009).

In a research work, Leung et al. (2012) reported how a glucoamylase- and protease-rich multi-enzyme solution was formed from waste bread using the fungi A. awamori and A. oryzae. Their SSF-based biorefining could be divided into three important steps as shown in Figure 4: (1) SSF of a selected fungus was carried out on solid waste material to obtain enzyme-rich fungal solids, (2) the fermented solids were subsequently added to a media suspension to produce a nutrient-rich hydrolysate with optimal $\mathrm{C} / \mathrm{N}$ source, and (3) another subsequent bacterial fermentation was carried out using the waste solid hydrolysate for the production of chemicals or targeted products. This strategy was also followed by Sun et al. (2014) to use mixed food waste directly collected from restaurants without pre-treatment as a renewable feedstock in succinic fermentation. A nutrient-complete medium (food waste hydrolysate) was produced using fungal mashes with A. awamori and A. oryzae containing appropriate levels of carbon and nitrogen sources utilized in the subsequent Actinobacillus succinogenes and recombinant Escherichia coli fermentation to produce succinic acid.

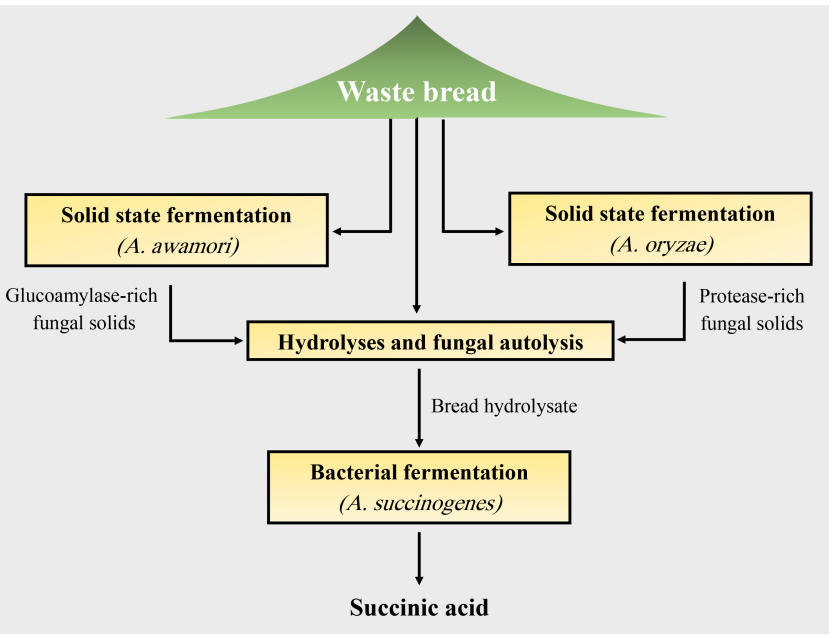

Fig.4. Novel bioprocess based on the production of amylolytic and proteolytic enzymes via SSF followed by subsequent submerged fermentation. Adapted from Leung et al. (2012).

Prior to that, Koutinas et al. (2010) designed an integrated biorefinery that produced high-quality wheat flour and upgraded the by-product stream into a nutrient-enrichment animal feed and added-value chemicals through microbial bioconversion. Figure 4 shows this process based on the bioproduction of succinic acid. One of the processes presented in Figure 5 used wheat bran in fungal SSF for enzyme production. This was then used in hydrolysis reactions to produce nutrient-rich hydrolysates from whea macromolecules (e.g., starch, protein). The nutrient-rich hydrolysate was then converted into the desired products by proper fermentation as shown in Figures 3 and 4.

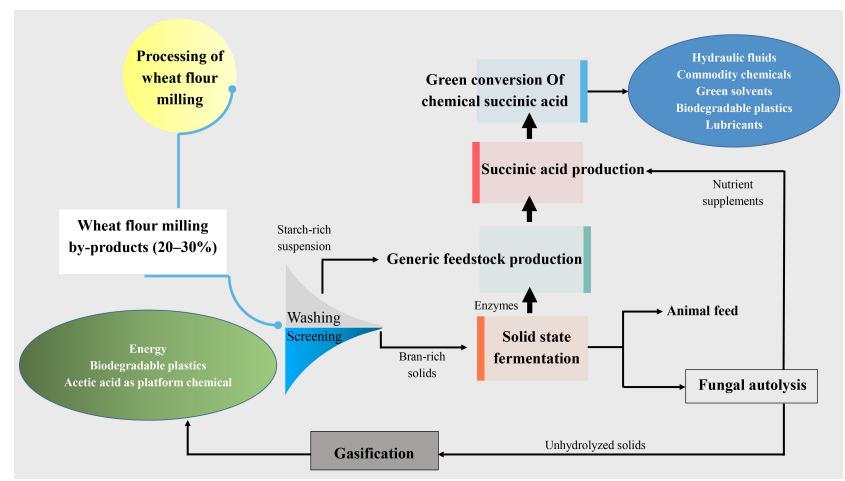

Fig.5. Schematic diagram of SSF rules in a possible biorefinery utilizing wheat flour milling by-products to produce added-value products. Adapted from Koutinas et al. (2010).

Another work by Botella (2007) explained how nutrient-rich hydrolysate was produced via SSF of wheat grains using A. awamori and followed next by SmF by Wautersia eutropha to produce the biodegradable plastic PHB and by Saccharomyces cerevisiae for ethanol production. Salakkam (2012) worked with nutrient-rich hydrolysate derived from rapeseed meal via SSF by $A$. oryzae followed by the hydrolysis of fermented solids to produce hydrolysate, which later was used for PHB production through SmF by Cupriavidus necator.

Added-value technology through microbial bioconversion technology will have a powerful impact on food and agro-industry waste processing and create exciting opportunities for addressing environmental issues and economic concerns (Iyayi and Aderolu, 2004). SSF with the use of 
microorganisms could lower operating costs by eliminating the need to purchase unnecessarily purified commercial enzymatic products (Melikoglu, 2008; Leung et al., 2012; Melikoglu et al., 2010 and 2013a). In addition, nutrient-rich hydrolysates with high glucose (Botella, 2007) and free amino nitrogen (FAN) (Leung et al., 2012; Sun et al., 2014) levels were shown to have great potential to replace more expensive synthetic media. Kwan et al. (2016) demonstrated the bioconversion of mixed food waste and bakery waste through fungal SSF by A. awamori 14331. After fungal SSF, fungal hydrolyses were performed in order to recover nutrients such as glucose, fructose, and FAN which are essential requirements for the subsequent lactic acid fermentation of Lactobacillus casei Shirota to produce lactic acid. Later, Kwan et al. (2017) developed further process to investigate the behavior and lactic acid production by Streptococcus thermophilus YI-B1 and L. casei Shirota during fermentation process using semi-defined medium and food waste derived media and found that the varied composition of food waste, enzyme loading, and solid-to-liquid ratio led to different nutrient composition and levels of the hydrolysate.

A potential integrated biorefinery based on food and agricultural industry waste solids can be summarized in the schematic diagram in Figure 6. At the end of SSF, hydrolysates are mixed with water and could be directly used for subsequent fermentation. However, nutrient-complete generic fermentation can be achieved with another step, continuing with simultaneous hydrolyses and fungal autolysis. In this step, enzyme activity, such as glucoamylase and protease activity, continues to degrade the solids from the fermented substrates to produce glucose and FAN.

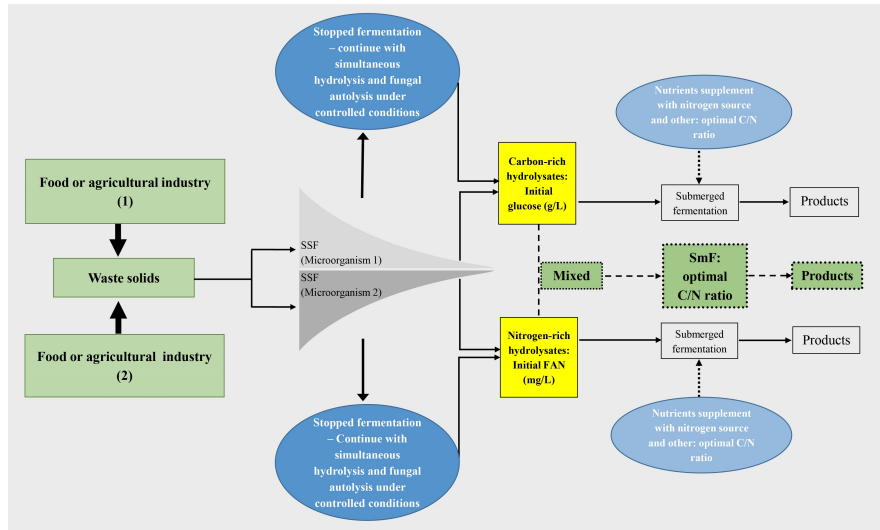

Fig.6. Summary of a novel process strategy for biorefineries based on SSF to produce generic fermentation feedstocks.

Research has shown that hydrolysates can either be used separately or in a mixture. Nutrient supplements might need to be added if separate feedstocks are used. With the respect to this, if carbon-rich hydrolysates from one microorganism are used, nutrients with a nitrogen source should be added. Likewise, if hydrolysates rich in nitrogen from a second microorganism are used, nutrients with a carbon source might be added. As a result, it has been proved that the performance of microorganisms is extremely efficient when both generic fermentation feedstocks are used together in a mixture. This is due to achieving optimal nutrient media with carbon and nitrogen sources $(\mathrm{C} / \mathrm{N}$ ratio) to support growth of microorganisms for selected fermentations. Such biorefining strategy provides complete feedstocks for subsequent microbial fermentation and leads to the production of chemicals and of targeted addedvalue products (Webb et al., 2005; Webb, 2007). According to Koutinas et al. (2010), three steps are required to produce a nutrient-complete medium for microbial fermentation: (i) on-site enzyme production through SSF or SmF; (ii) enzymatic hydrolysis of substrate suspensions, and (iii) fungal autolysis for production of hydrolysate with a high nutrient composition.

It is predicted that SSF technology will appeal to countries that have a high level of agro-industry waste, as this can be used as inexpensive raw material. On top of that, advanced biorefining strategies have been restructured in order to reduce environmental impact, improve overall economics, and meet market and societal needs (Webb et al., 2005; Koutinas et al., 2004, 2005, 2007a, 2007b, and 2010; Melikoglu, 2008; Melikoglu et al., 2013a and b; Webb,
2017). The promising results taken from these research activities have led to the conclusion that biomass from renewable resources, such as food and agro-industry waste, has practical benefits and should be further taken advantage of within future biorefining strategies.

\section{Investing in a green sustainable future}

The biorefinery concept can be filled with real world examples of processes that make use of biomass to produce useful products (Webb, 2007). SSF bioprocessing and a range of possibilities to integrate biorefining in the processing industry will fill the concept with some meaning. For example, wheat is one of the main agricultural crops in the United Kingdom (UK). As reported by the Department for Environment Food and Rural Affairs of the UK in the year 2016, the country produces about 14.5 million tonnes of wheat per year, and this agricultural activity is estimated to produce about 1.61 million tonnes of wheat bran. Through many generations, wheat bran has been used as an animal feed and can be categorized as waste. Value addition of wheat bran through microbial fermentation technology using selected microorganisms can improve the nutritional content and make it more valuable. The value of wheat bran can be improved through fermentation technology either by using SSF or SmF. These two techniques are not entirely independent. SSF has been chosen since it appears to be exceptional and more favorable than $\mathrm{SmF}$ in several aspects where it gives advantages in terms of biological, processing, environmental and economic aspects to produce food, enzymes, chemicals and bio-oils. Biomass such as waste and by-product streams from existing industrial sectors (e.g., food industry, pulp and paper industry, biodiesel and bioethanol production) can also be used as renewable resources for both biorefinery development and the production of nutrient-complete fermentation feedstocks (Koutinas et al., 2014). Another biomass is food waste, which is currently generated in huge quantities worldwide. It was estimated about one third of food produced for human consumption is lost or wasted globally that results in the generation of 1.3 billion metric tonne of food waste per year (Gustavsson et al., 2011). Proposed processing strategies involving biorefinery approaches based on both chemical and biological technologies will definitely help (Lin et al., 2014; Turon et al., 2014). As reported by Lam et al. (2014), for the economic feasibility of pilot-scale fermentation of succinic acid from bakery waste in Hong Kong, it is possible to generate US\$ 374,041/year overall revenue by converting 1 tonne/d of bakery waste. Another interesting work is utilization of different feedstock formulation strategies based on the utilization of microbial feedstocks produced from bakery waste through the proposed Starbucks biorefinery development in Hong Kong for the production of biodegradable plastics, succinic acid, and multi-enzyme solutions (Lin, 2013). Other than that is spent ground coffee obtained after brewing the coffee beans which is an abundant by-product of the coffee industry making it a promising and interesting feedstock for a biorefinery (Jooste et al. 2013; Rocha et al., 2014; Burniol-Figols et al., 2016). This is important for attracting investment and industrialization interest in the biorefinery process using domestic waste as raw material.

As mentioned earlier, SSF offers a more favorable environment for fungal growth, yielding higher productivity in a relatively low-cost process by using nutrient-rich agro-industrial residues as substrates (Holker et al., 2004; Cerda et al., 2017a). Note-worthy to say, with the increasing interest in SSF nowadays, researchers are keen to discover as many new ways to explore the usage of this technology as possible to develop new addedvalue materials from by-products. The technology know-how, protocol, and manufacturing process will be obtained and optimized taking into account raw materials, technologies, processing routes, products, technical, economical, and environmental aspects (Moncada et al., 2016). The use of renewable resources will make an essential contribution towards sustainable development while, at the same time; the generation of pollutants or harmful waste during product manufacture can be minimized.

- Future biorefinery studies can be carried out to use the possible solid state bioreactor for the production of nutrient-rich hydrolysate for sequel fermentation for the production of valuable chemicals. The productivity of the systems can be enhanced by modification and adding several control parameters for better control of SSF processes. 
- SSF has proved to be excellent technology for solid waste treatment. It can be suggested that food and agro-industry solid waste can be utilized for the production of various added-value products. Industrial bodies should consider this scenario as part of their strategy for tackling the food and agro-industry waste problem and for the environmentally friendly production of biomaterial, enzymes, secondary metabolites, chemicals, and even biofuels. In many countries food waste for example, is currently landfilled or incinerated together with other combustible wastes for possible energy recovery (Kiran et al., 2014a; Panda et al., 2016), while through circular economy, it could serve as a promising source of energy and value-added products, especially in developing countries (Nizami et al., 2017). Therefore, the issue of solid waste being thrown onto the land and the subsequent environmental problems could be overcome (BastidalOyanedel et al., 2016; Koutinas and Kookos, 2016; Vasquez et al., 2016).

Overall, the value of food and agro-industrial waste can be improved through microbial SSF technology and thus, SSF can be an ideal platform for biomass biochemical conversion for bio-based products (Chen and Wang, 2017). Improvements in the quality of food and agro-industrial waste can be associated with the improved value of food and agro-industrial waste (Madeira $\mathrm{Jr}$ et al., 2017). In another word, these approaches may lead to associate improvement in food and agro-industrial waste quality and to manage the issue of solid wastes in a green approach (Yazid et al., 2017). The microorganism chosen must also be capable of utilizing all the nutrients contained in food and agro-industrial waste and provide unique microenvironments conducive to microbial growth and metabolic activity (Kiran et al., 2014a; Huynh et al., 2016; Yang et al., 2017). The quality of food and agro-industrial waste may be improved either in a nutritional way or by improving its processing properties. Therefore, the microbial bioconversion technology involved may allow novel alteration of nutritional quality (Kiran et al., 2014b; Panda et al., 2016; Vasquez et al., 2016). Potential value-added by-products from food and agro-industrial waste fractions could be then used for the production of various co-products, such as methane, hydrogen, ethanol, butanol, cosmeceutical, pharmaceutical and nutraceutical products, enzymes, organic acids, natural biopigments, feed and food ingredients, prebiotics for animals, natural polymers (e.g., arabinoxylans, B-glucans), monomers (e.g., glucose, xylose, arabinose, succinic acid, lactic acid), or oil components (e.g., triglycerides, sterols). Definitely, the main benefit anticipated by using microbial bioconversion technology is to add value to food and agro-industrial waste, which can be identified, from the product quality and safety of the final fermented products. It is desirable to use this as a renewable resource for sustainable production of value-added products through microbial fermentation technology and SSF is a promising technology, however, rising concerns related to scale up and reproducibility in a productive process, which should be addressed in the future (Cerda et al., 2017b).

\section{Conclusions}

Advances in the understanding of microbiology and of the composition of targeted products and their raw materials (biomass), as well as the development of advanced SSF bioreactors, allow more consistent research and development in SSF. Thus, we arrive at the modern day bioprocessing and microbial fermentation processes. Despite many limitations, many industrial facilities worldwide successfully operate SSF processes, although some of them produce relatively small quantities of high added-value products that do not require large-scale bioreactors. In other cases, the bioreactors do not operate optimally, or bioreactors that are not easily adaptable for different processes are used. We believe that in the near future flexible and optimum performance large-scale SSF bioreactors will be designed, built, and operated successfully, although more engineering research is needed. These bioreactors will use low-cost and reliable instruments, especially designed for SSF, and sophisticated control strategies that will include advanced control techniques such as expert- and model-based controlled systems. Indeed, the biorefinery idea and prospect can be pervaded with real world examples to produce functional and valuable products. On top of that, it will add value to the sustainable use of biomass and make a significant contribution to sustainable development. Last but not least, the ability of microorganisms, especially filamentous fungi, to convert biomass through SSF bioconversion will have a great impact on food and agro-industry in every aspect of life from food and medicine to fuel. This is a future that undoubtedly will present challenges, but one that we believe we should embrace.

\section{Acknowledgements}

This work was funded by Malaysian Agricultural Research and Development Institute (MARDI) and Government of Malaysia through the scheme's study leave.

\section{References}

[1] Abdul Manan, M., Webb, C., 2016. Extracted substrate colour as an indicator of fungal growth in solid state fermentation. Malaysian J. Microbiol. 12(6), 445-449.

[2] Amore, A., Faraco, V., 2012. Potential of fungi as category I consolidated bioprocessing organisms for cellulosic ethanol production. Renew. Sust. Energy Rev. 16(5), 3286-3301.

[3] Azeredo, L.A.I., Gomes, P.M., Sant'Anna Jr, G.L., Castilho, L.R., Freire, D.M.G., 2007. Production and regulation of lipase activity from Penicillium restrictum in submerged and solid-state fermentation. Curr. Microbiol. 54(5), 361-365.

[4] Bastidas-Oyanedel, J.R., Fang, C., Almardeai, S., Javid, U., Yousuf, A., Schmidt, J.E., 2016. Waste biorefinery in arid/semi-arid regions. Bioresour. Technol. 215, 21-28.

[5] Behera, S., Ray, R.C., 2016. Solid state fermentation for production of microbial cellulases: recent advances and improvement strategies. Int. J. Biol. Macromol. 86, 656-669.

[6] Berntsson, T., Sanden, B., Olsson, L., Asblad, A., 2012. What is biorefinery? In: Sanden, B., Pettersson, K. (Eds.), Systems perspective on biorefineries. Gothenburg: Chalmers University of Technology, pp. 16-25.

[7] Bhanja, T., Rout, S., Banerjee, R., Bhattacharyy, B.C. 2007.Comparative profiles of $\alpha$-amylase production in conventional tray reactor and GROWTEK bioreactor. Bioprocess Biosyst. Eng. 30(5), 369-376.

[8] Biz, A., Finkler, A.T.J., Pitol, L.O., Medina, B.S., Krieger, N. Mitchell, D.A., 2016. Production of pectinase by solid-state fermentation of a mixture of citrus waste and sugarcane bagasse in a pilot-scale packed-bed bioreactor. Biochem. Eng. J. 111, 54-56.

[9] Botella, C.F., Diaz, A.B., Wang, R.H., Koutinas, A., Webb, C., 2009. Particulate bioprocessing: a novel process strategy for biorefineries. Process Biochem. 44, 546-555.

[10] Botella, C.F., 2007. Particulate bioprocessing: a novel process strategy for biorefineries. $\mathrm{PhD}$ Thesis. The University of Manchester, United Kingdom.

[11] Burniol-Figols, A., Cenian, K., Skiadas, I.V., Gavala, H.N., 2016. Integration of chlorogenic acid recovery and bioethanol production from spent coffee grounds. Biochem. Eng. J. 116, 54-64.

[12] Castilho, L.R., Mitchell, D.A., Freire, D.M.G., 2009. Production of polyhydroxyalkanoates (PHAs) from waste materials and byproducts by submerged and solid-state fermentation. Bioresour. Technol. 100(23), 5996-6009.

[13] Castilho, L.R., Polato, C.M.S., Baruque, E.A., Sant'Anna Jr, G.L., Freire, D.M.G., 2000. Economic analysis of lipase production by Penicillium restrictum in solid-state fermentation and submerged fermentation. Biochem. Eng. J. 4(3), 239-247.

[14] Cavalcanti, E.D.C., Gutarra, M.L.E., Freire, D.M.G., Castilho, L.R., Junior, G.L.S., 2005. Lipase production by solid state fermentation in fixed-bed bioreactors. Braz. Arch. Biol. Technol. 48, 79-84

[15] Cerda, A., Mejias, L., Gea, T., Sanchez, A., 2017a. Cellulase anc xylanase production at pilot scale by solid-state fermentation from coffee husk using specialized consortia : the consistency of the process and the microbial communities involved. Bioresour. Technol. 243, 1059-1068

[16] Cerda, A., Gea, T., Vargas-Garcia, M.C., Sanchez, A., 2017b. Towards a competitive solid state fermentation: cellulases production from coffee husk by sequential batch operation and role of microbial diversity. Sci. Total Environ. 589, 56-65.

[17] Cerda, A., El-Bakry, M., Gea, T., Sanchez, A., 2016. Long term enhanced solid-state fermentation: inoculation strategies for amylase 
production from soy and bread wastes by Thermomyces sp. in a sequential batch operation. J. Environ. Chem. Eng. 4, 2394-2401.

[18] Chakradhar, D., Javeed, S., Sattur, A.P., 2009. Studies on the production of nigerloxin using agro-industrial residues by solid-state fermentation. J. Ind. Microbiol. Biotechnol. 36(9), 1179-1187.

[19] Chen, H., Wang, L., 2017. Microbial fermentation strategies for biomass conversion. In: Chen, H., Wang, L. (Eds.), Technologies for biochemical conversion of biomass. Academic Press, pp. 165-196.

[20] Chen, H., Xu, F., Li, Z., 2002. Solid-state production of biopulp by Phanerochaete shrysosporium using steam-exploded wheat straw as substrate. Bioresour. Technol. 81(3), 261-263.

[21] Colla, L.M., Ficanha, A.M.M., Rizzardi, J., Bertolin, T.E., Reinehr, C.O., Costa, J.A.V., 2015. Production and characterization of lipases by two isolates of Aspergillus through solid-state and submerged fermentation. Biomed Res. Int. 1-9.

[22] Colla, L.M., Rizzardi, J., Pinto, M.H., Reinehr, C.O., Bertolin, T.E., Costa, J.A.V., 2010. Simultaneous production of lipases and biosurfactants by submerged and solid-state bioprocesses. Bioresour. Technol. 101(21), 8308-8314.

[23] Cristobal, N.A., Gerardo, G.S., Plilia, A., Raul, R.H., Jose, L.M.H., Juan, C.C.E., 2008. Perspectives of solid state fermentation for production of food enzymes. Am. J. Biochem. Biotechnol. 4(4), 354-366.

[24] Dalsenter, F.D.H., Viccini, G., Barga, M.C., Mitchell, D.A., Krieger, N., 2005. A mathematical model describing the effect of temperature variations on the kinetics of microbial growth in solid-state culture. Process Biochem. 40, 801-807.

[25] de Jong, E., Jungmeier, G., 2015. Biorefinery concepts in comparison to petrochemical refineries. In: Pandey, A., Hofer, R., Larroche, C., Taherzadeh, M., Nampoothiri, M. (Eds.), Industrial Biorefineries and White Biotechnology. Elsevier, United Kingdom, pp. 3-33.

[26] De la Cruz-Quiroz, R., Roussos, S., Hernandez-Castillo, D., RodriguezHerrera, R., Lopez-Lopez, L., Castilho, F., Aguilar, C.N., 2017. Solid state fermentation in a bag bioreactor: effect of corn cob mixed with phytopathogen biomass on spore and cellulose production by Trichoderma asperellum. In: Jozala, A.F. (Eds.), Fermentation processes. pp. 43-56.

[27] Department for environment food and rural affairs. Farming statistics first estimates of 2016 UK wheat and barley production, National Statistics, 2016.

[28] Dey, T.B., Kuhad, R.C., 2014. Enhanced production and extraction of phenolic compounds from wheat by solid-state fermentation with Rhizopus oryzae RCK2012. Biotechnol. Rep. 4, 120-127.

[29] Dias, G.S., de Lima Luz Jr, L.F., Mitchell, D.A., Krieger, N., 2017. Scale-up of biodiesel synthesis in a closed-loop packed bed bioreactor system using the fermented solid produced by Burkholderia lata LTEB11. Chem. Eng. J. 316, 341-349.

[30] Diaz, J.C.M., Rodriguez, J.A., Roussos, S., Cordova, J., Abousalham, A., Carriere, J.B., 2006. Lipase from the thermotolerant fungus Rhizopus homothallicus is more thermostable when produced using solid state fermentation than liquid fermentation procedures. Enzyme Microb. Technol. 39, 1042-1050.

[31] Dikshit, R., Tallapragada, P., 2015. Screening and optimization of $\gamma$ aminobutyric acid production from Monascus sanguineus under solidstate fermentation. Front. Life Sci. 8(2), 172-181.

[32] Dorado, P.M., Lin, C.S.K., Koutinas, A., Du, C., Wang, R., Webb, C., 2009. Cereal-based biorefinery development: utilisation of wheat milling by-products for the production of succinic acid. J. Biotechnol. 143(1), 51-59.

[33] Doriya, K., Jose, N., Gowda, M., Kumar, D.S., 2016. Solid-state fermentation vs submerged fermentation for the production of Lasparaginase. Adv. Food Nutr. Res. 78, 115-135.

[34] Du, C., Lin, C.S.K., Koutinas, A., Wang, R., Dorado, P., Webb, C., 2008. A wheat biorefining strategy based on solid-state fermentation for fermentative production of succinic acid. Bioresour. Technol. 99(17), 8310-8315.

[35] El-Bakry, M., Abraham, J., Cerda, A., Barrena, R., Ponsa, S., Gea, T., Sanchez, A., 2015. From waste to high value added products: novel aspects of SSF in the production of enzymes. Crit. Rev. Environ. Sci. Technol. 45(18), 1999-2042.
[36] El-Naggar, M.Y., El-Assar, S.A., Abdul-Gawad, S.M., 2009. SolidState Fermentation for the Production of Meroparamycin by Streptomyces sp. strain MAR01. J. Microbiol. Biotechnol. 19(5), 468-473.

[37] Ertan, F., Balkan, B., Yarkin, Z., 2014. Determination of the effects of initial glucose on the production of $\alpha$-amylase from Penicillium sp. under solid-state and submerged fermentation. Biotechnol. Biotechnol. Equip. 28(1), 96-101.

[38] Fanaei, M.A., Vaziri, B.M., 2009. Modelling of temperature gradients in packed-bed solid-state bioreactors. C Chem. Eng. Process. Process Intensif. 48(1), 446-451.

[39] Farinas, C.S., 2015. Developments in solid-state fermentation for the production of biomass-degrading enzymes for the bioenergy sector. Renew. Sust. Energy Rev. 52, 179-188.

[40] Farinas, C.S., Vitcosque, G.L., Fonseca, R.F., Neto, V.B., Couri, S., 2011. Modelling the effects of solid state fermentation operating conditions on endoglucanase production using an instrumented bioreactor. Ind. Crops Prod. 34(1), 1186-1192.

[41] Fatma, H.A.E.Z., Fadel, M., 2010. Production of bioethanol via enzymatic saccharification of rice straw by cellulase produced by Trichoderma reesei under solid state fermentation. N. Y. Sci. J. 3(4), 72-78.

[42] Finkler, A.T.J., Biz, A., Pitol, L.O., Medina, B.S., Luithardt, H., Luz Jr, L.F.L., Krieger, N., Mitchell, D.A., 2017. Intermittent agitation contributes to uniformity across the bed during pectinase production by Aspergillus niger grown in solid-state fermentation in a pilotscale packed-bed bioreactor. Biochem. Eng. J. 121, 1-12.

[43] Giles, R.L., Galloway, E.R., Elliot, G.D., Parrow, M.W., 2011. Twostage fungal biopulping for improved enzymatic hydrolysis of wood. Bioresour. Technol. 102(17), 8011-8016.

[44] Gregori, A., Svagelj, M., Voglar, D., Berovic, M., 2016. Growth characteristics and ergosterol content of Grifola frondosa in various solid-state substrates. Chem. Biochem. Eng. Q. 30(2), 183-188.

[45] Gustavsson, J., Cederberg, C., Sonesson, U., van Otterdijk, R., Meybeck, A., 2011. Global food losses and food waste - extent, causes and prevention food and agriculture organization of the United Nations (FAO), Rome, Italy, pp. 3-37.

[46] Hamidi-Esfahani, Z., Hejazi, P., Shojaosadati, S.A., Hoogschagen, M., Vasheghani-Farahani, E., Rinzema, A., 2007. A two-phase kinetic model for fungal growth in solid-state cultivation. Biochem. Eng. J. 36(2), 100-107.

[47] Hamidi-Esfahani, Z., Shojaosadatia, S.A., Rinzema, A., 2004. Modelling of simultaneous effect of moisture and temperature on Asepergillus niger growth in solid-state fermentation. Biochem. Eng. J. 21(3), 265-272.

[48] Hanc, A., Dreslova, M., 2016. Effect of composting and vermicomposting on properties of particle size fractions. Bioresour. Technol. 217, 186-189.

[49] Hansen, G.H., Lubeck, M., Frisvad, J.C., Lubeck, P.S., Andersen, B., 2015. Production of cellulolytic enzymes from ascomycetes: comparison of solid state and submerged fermentation. Process Biochem. 50(9), 1327-1341.

[50] Hashemi, M., Mousavi, S.M., Razavi, S.H., Shojaosadati, S.A., 2013. Comparison of submerged and solid state fermentation systems effects on the catalytic activity of Bacillus sp. KR-8104 $\alpha$ amylase at different $\mathrm{pH}$ and temperatures. Ind. Crops Prod. 43, 661 667.

[51] Holker, U., Hofer, M., Lenz, J., 2004. Biotechnological advantages of laboratory-scale solid-state fermentation with fungi. Appl. Microbiol. Biotechnol. 64, 175-186.

[52] Huynh, N.T., Smagghe, G., Gonzales, G.B., Camp, J.V., Raes, K. 2016. Extraction and bioconversion of kaempferol metabolites from cauliflower outer leaves through fungal fermentation. Biochem. Eng. J. 116, 27-33.

[53] Iyayi, E.A., Aderolu, Z.A., 2004. Enhancement of the feeding value of some agro-industrial by-products for laying hens after their solid state fermentation with Trichoderma viride. African J. Biotechnol. 3(3), 182-185.

[54] Jiang, H., Liu, G., Mei, C., Yu, S., Xiao, X., Ding, Y., 2012. Measurement of process variables in solid-state fermentation of 
wheat straw using FT-NIR spectroscopy and synergy interval PLS algorithm. Spectrochim. Acta, Part A. 97, 277-283.

[55] Jimenez-Penalver, P., Gea, T., Sanchez, A., Font, X., 2016. Production of sophorolipids from winterization oil cake by solid-state fermentation: optimization, monitoring and effect of mixing. Biochem. Eng. J. 115, 93-100.

[56] Jooste, T., Garcia-Aparicio, M.O., Brienzo, M., Van Zyl, W.H., Gorgens, J.F., 2013. Enzymatic hydrolysis of spent coffee ground. Appl. Biochem. Biotechnol. 169(8), 2248-2262.

[57] Khanahmadi, M., Roostaazad, R., Mitchell, D.A., Miranzadeh, M., Bozorgmehri, R., Safekordi, A., 2006. Bed moisture estimation by monitoring of air stream temperature rise in packed-bed solid-state fermentation. Chem. Eng. Sci. 61(17), 5654-5663.

[58] Khanahmadi, M., Roostaazad, R., Safekordi, A., Bozorgmehri, R., Mitchell, D.A., 2004. Investigating the use of cooling surfaces in solidstate fermentation tray bioreactors: modelling and experimentation. J. Chem. Technol. Biotechnol. 79(11), 1228-1242.

[59] Kim, S., Dale, B.E., 2004. Global potential bioethanol production from wasted crops and crop residues. Biomass Bioenergy. 26(4), 361-375

[60] Kiran, E.U., Trzcinski, A.P., Liu, Y., 2014a. Glucoamylase production from food waste by solid state fermentation and its evaluation in the hydrolysis of domestic food waste. Biofuel Res. J. 1(3), 98-105.

[61] Kiran, E.U., Trzcinski, A.P., Ng, W.J., Liu, Y., 2014b. Enzyme production from food wastes using a biorefinery concept. Waste Biomass Valorization. 5(6), 903-917.

[62] Koutinas, A., Kookos, I., 2016. Advances on biorefinery engineering and food supply chain waste valorisation. Biochem. Eng. J. 116, 1-210.

[63] Koutinas, A.A., Vlysidis, A., Pleissner, D., Kopsahelis, N., Garcia, I.L., Kookos, I.K., Papanikolaou, S., Kwan, T.H., Lin, C.S.K., 2014. Valorization of industrial waste and by-product streams via fermentation for the production of chemicals and biopolymers. Chem. Soc. Rev. 43(8), 2587-2627.

[64] Koutinas, A.A., Wang, R.H., Webb, C., 2004. Restructuring upstream bioprocessing: technological and economical aspects the production of generic microbial feedstock from wheat. Biotechnol. Bioeng. 85(5), 524-538.

[65] Koutinas, A.A., Wang, R.H., Webb, C., 2005. Development of a process for the production of nutrient supplements for fermentations based on fungal autolysis. Enzyme Microb. Technol. 36(5-6), 629-638.

[66] Koutinas, A.A., Arifeen, N., Wang, R.H., Webb, C., 2007a. Cerealbased biorefinery development: integrated enzyme production for cereal flour hydrolysis. Biotechnol. Bioeng. 97(1), 61-72.

[67] Koutinas, A.A., Wang, R.H., Webb, C., 2007b. The biochemurgist bioconversion of agricultural raw materials for chemical production. Biofuels, Bioprod. Biorefin. 1(1), 24-38.

[68] Koutinas, A.A., Wang, R., Campbell, M., Webb, C., 2010. A whole crop biorefinery system: a closed system for the manufactures of non-food products. In: Kamm, B., Gruber, P.R., Kamm, M. (Eds.), Biorefineries - Industrial Processes and Products: Status Quo and Future Directions. WILEY-VCH Verlag GmBH \& Co. KGaA, Weinheim, pp. 165-191.

[69] Kumar, M., Singhal, A., Thakur, I.S., 2016. Comparison of submerged and solid state pretreatment of sugarcane bagasse by Pandoraea sp. ISTKB: enzymatic and structural analysis. Bioresour. Technol. 203, 1825.

[70] Kwan, T.H., Vlysidis, A., Wu, Z., Hu, Y., Koutinas, A., Lin, C.S.K., 2017. Lactic acid fermentation modelling of Streptococcus thermophilus YI-B1 and Lactobacillus casei Shirota using food waste derived media. Biochem. Eng. J. 127, 97-109.

[71] Kwan, T.H., Hu, Y., Lin, C.S.K., 2016. Valorisation of foof waste via fungal hydrolysis and lactic acid fermentation with Lactobacillus casei Shirota. Bioresour. Technol. 217, 129-136.

[72] Lam, K.F., Leung, C.C.J., Lei, H.M., Lin, C.S.K., 2014. Economic feasibility of a pilot-scale fermentative succinic acid production from bakery wastes. Food Bioprod. Process. 92, 282-290.

[73] Lange, L., 2017. Unlocking the full potentials of the biomass: new technologies for cascading use of crop residues and industrial side streams. International Conference on Sustainable Agriculture and Bioeconomy. 27 Febuary - 2 March 2017. Bangkok International Trade and Exhibition Centre (BITEC), Bangkok, Thailand.
[74] Leung, C.C.J., Cheung, A.S.Y., Zhang, A.Y.Y.Z., Lam, K.F., Lin, C.S.K., 2012. Utilisation of waste bread for fermentative succinic acid production. Biochem. Eng. J. 65, 10-15.

[75] Lin, C.S.K., Koutinas, A.A., Stamatelatou, K., Mubofu, E.B., Matharu, A.S., Kopsahelis, N., Pfaltzgraff, L.A., Clark, J.H., Papanikolaou, S., Kwan, T.H., Luque, R., 2014. Current and future trends in food waste valorization for the production of chemicals, materials and fuels: a global perspective. Biofuels, Byprod. Biorefin. 8 (5) 686-715.

[76] Lin, C.S.K., 2013. Starbucks biorefinery development: Valorization of bakery waste from Starbucks Hong Kong for the production of biodegradable plastics, succinic acid and multi-enzyme solutions. $2^{\text {nd }}$ International Conference and Exhibition on Food Technology, Bioprocess and Cell Culture. Kansas City, USA. DOI: 10.4172/2157-7110.S1.015.

[77] Linde, G.A., Magagnin, C., Costa, J.A.V., Bertolin, T.E., Colauto N.B., 2007. Column bioreactor use for optimization of pectinase production in solid substrate cultivation. Braz. J. Microbiol. 38, $557-$ 562.

[78] Madeira Jr, J.V., Contesini, F.J., Calzado, F., Rubio, M.V., Zubieta, P., Lopes, D.B., de Melo, R.R., 2017. Agro-industrial residues and microbial enzymes: an overview on the eco-friendly bioconversion into high value-added products. In: Brahmachari, G., Demian, A.L., Adrio, J. (Eds.), Biotechnology of microbial enzymes - Production, biocatalysis and industrial applications. Academic Press, pp. 475511.

[79] Mahro, B., Timm, N., 2007. Potential of biowaste from the food industry as a biomass resource. Eng. Life Sci. 7(5), 457-468.

[80] Mata-Gomez, M., Mussatto, S.I., Rodriguez, R., Teixeira, J.A., Martinez, J.L., Hernandez, A., Aguilar, C.N., 2015. Gallic acid production with mouldy polyurethane particles obtained from solid state culture of Aspergillus niger GH1. Appl. Biochem. Biotechnol. 176(4), 1131-1140.

[81] Melikoglu, M., Lin, C.S.K., Webb, C., 2015. Solid state fermentation of waste bread pieces by Aspergillus awamori: analysing the effects of airflow rate on enzyme production in packed bed bioreactors. Food Bioprod. Process. 95, 63-75.

[82] Melikoglu, M., Lin, C.S.K., Webb, C., 2013a. Stepwise optimisation of enzyme production in solid state fermentation of waste bread pieces. Food Bioprod. Process. 91(4), 638-646

[83] Melikoglu, M., Lin, C.S.K., Webb, C., 2013b. Kinetic studies on the multi-enzyme solution produced via solid state fermentation of waste bread by Aspergillus awamori. Biochem. Eng. J. 80, 76-82.

[84] Mitchell, D.A., de Lima Luz, L.F., Krieger, N., 2011. Bioreactors for solid-state fermentation. In: Moo-Yong, M., (Eds.), Comprehensive Biotechnology. Elsevier, Second edition, pp. 347-360.

[85] Melikoglu, M., 2008. Production of sustainable alternatives to petrochemicals and fuels using waste bread as a raw material. $\mathrm{PhD}$ thesis, The University of Manchester, United Kingdom.

[86] Mitchell, D.A., Berovic, M., Krieger, N., 2000. Biochemical engineering aspects of solid state bioprocessing. Adv. Biochem. Eng. Biotechnol. 68, 61-138.

[87] Moncada, J.B., Aristizabal, V.M., Cardona, C.A.A., 2016. Design strategies for sustainable biorefineries. Biochem. Eng. J. 116, 122134.

[88] Mrudula, S., Murugammal, R., 2011. Production of cellulose by Aspergillus niger under submerged and solid state fermentation using coir waste as a substrate. Braz. J. Microbiol. 42(3), 1119-1127.

[89] Nagel, F.J.J.I., Tramper, J., Bakker, M.S.N., Rinzema, A., 2001a Temperature control in a continuously mixed bioreactor for solidstate fermentation. Biotechnol. Bioeng. 72(2), 220-230.

[90] Nagel, F.J.J.I., Tramper, J., Bakker, M.S.N., Rinzema, A., 2001b. Model for on-line moisture-content control during solid-state fermentation. Biotechnol. Bioeng. 72(2), 232-243.

[91] Nair, S.G., Sindhu, R., Shashidhar, S., 2008. Fungal xylanase production under solid state and submerged fermentation conditions. Afr. J. Microbiol. Res. 2, 82-86.

[92] Nalini, S., Parthasarathi, R., 2014. Production and characterization of rhamnolipids produced by Serratia rubdaea SNAU02 under 
solid-state fermentation and its application as biocontrol agent. Bioresour. Technol. 173, 231-238.

[93] Naveena, B.J., Altaf, M.D., Bhadriah, K., Reddy, G., 2005. Selection of medium components by Plackett-Burman design for production of $\mathrm{L}(+)$ lactic acid by Lactobacillus amylophilus GV6 in SSF using wheat bran. Bioresour. Technol. 96(4), 485-490.

[94] Nizami, A.S., Rehan, M., Waqas, M., Naqvi, M., Ouda, O.K.M., Shahzad, K., Miandad, R., Khan, M.Z., Syamsiro, M., Ismail, I.M.I., Pant, D., 2017. Waste biorefineries: enabling circular economies in developing countries. Bioresour. Technol. 241, 1101-1117.

[95] Orzua, M.C., Mussatto, S.I., Contreras-Esquivel, J.C., Rodriguez, R., de la Garza, G., Teixeira, J.A., Aguilar, C.N., 2009. Exploitation of agro industrial wastes as immobilization carrier for solid-state fermentation. Ind. Crops Prod. 30(1), 24-27.

[96] Panda, S.K., Mishara, S.S., Kayitesi, E., Ray, R.C., 2016. Microbialprocessing of fruit and vegetables wastes for production of vital enzymes and organic acids: biotechnology and scopes. Environ. Res. 146, 161172.

[97] Pandey, A., Soccol, C.R., Mitchell, D.A., 2000. New developments in solid state fermentation. I: processes and products. Process Biochem. 35, 1153-1169.

[98] Panesar, P.S., Kaur, R., Singla, G., Sangwan, R.S., 2016. Bio-processing of agro-industrial wastes for production of food-grade enzymes: progress and prospects. Appl. Food Biotechnol. 3(4), 208-277.

[99] Patil, N.S., Jadhav, J.P., 2014. Enzymatic production of N-acetyl-Dglucosamine by solid state fermentation of chitinase by Penicillium ochrochloron MTCC 517 using agricultural residues. Int. Biodeterior. Biodegrad. 91, 9-17.

[100] Patil, S.R., Dayanand, A., 2006. Production of pectinase from deseeded sunflower head by Aspergillus niger in submerged and solid-state conditions. Bioresour. Technol. 97(16), 2054-2058.

[101] Pengnoi, P., Mahawan, R., Khanongnuch, C., Lumyong, S., 2017. Antioxidant properties and production of monacolin K, citrinin, and red pigments during solid state fermentation of purple rice (Oryzae sativa) varieties by Monascus purpureus. Czech J. Food Sci. 35(1), 32-39.

[102] Pitol, L.O., Biz, A., Mallmann, E., Krieger, N., Mitchell, D.A., 2016. Production of pectinase by solid-state fermentation in a pilot-scale packed-bed bioreactor. Chem. Eng. J. 283, 1009-1018.

[103] Poletto, P., Polidoro, T.A., Zeni, M., da Silveira, M.M., 2017. Evaluation of the operating conditions for the solid-state production of pectinases by Aspergillus niger in a bench-scale, intermittently agitated rotating drum bioreactor. LWT Food Sci. Technol. 79, 92-101.

[104] Postemsky, P.D., Bidegain, M.A., Gonzalea-Matute, R., Figlas, N.D., Cubitto, M.A., 2017. Pilot-scale bioconversion of rice and sunflower agro-residues into medicinal mushrooms and laccase enzymes through solid-state fermentation with Ganoderma lucidum. Bioresour. Technol. 231, 85-93.

[105] Raghunath, R., Radhakrisna, A., Manikandan, N., Nathiya, K., Palaniswamy, M., 2012. Optimised production of lovastatin through solid state fermentation by endophytic fungi. Int. J. Pharma Bio. Sci. 3(3) 562-570.

[106] Rahardjo, Y.S.P., Tramper, J., Rinzema, A., 2006. Modelling conversion and transport phenomena in solid-state fermentation: a review and perspectives. Biotechnol. Adv. 24(2), 161-179.

[107] Ramadas, N.V., Singh, S.K., Soccol, C.R., Pandey, A., 2009. Polyhydroxybutyrate production using agro-industrial residues as substrate by Bacillus sphaericus NCIM 5149. Braz. Archi. Biology Technol. 52(1), 17-23.

[108] Rocha, M.V.P., de Matas, L.J.B.L., De Lima, L.P., Figueiredo, P.M.D.S., Lucena, I.L., Fernandes, F.A.N., Goncalves, L.R.B., 2014. Ultrasound-assisted production of biodiesel and ethanol from spent coffee grounds. Bioresour. Technol. 167, 343-348.

[109] Rosales, E., Couto, S.R., Sanroman, M.A., 2007. Increased laccase production by Trametes hirsuta grown on ground orange peelings. Enzyme Microb. Technol. 40(5), 1286-1290.

[110] Ruiz, H.A., Rodriguez-Jasso, R.M., Rodriguez, R., Contreras-Esquivel, J.C., Aguilar, C.N., 2012. Pectinase production from lemon peel pomace as support and carbon source in solid-state fermentation column-tray bioreactor. Biochem. Eng. J. 65, 90-95.
[111] Saha, M.L., Takahashi, F., 1997. Continuous citric acid fermentation by magnetic rotating biological contactors using Aspergillus niger AJ 117173. J. Ferment. Bioeng. 84(3), 244-248.

[112] Saithi, S., Tongta, A., 2016. Phytase production of Aspergillus niger on soybean meal by solid-state fermentation using rotating drum bioreactor. Agric. Agric. Sci. Procedia 11, 25-30.

[113] Salakkam, A., 2012. Bioconversion of biodiesel by-products to value-added chemicals. PhD thesis. The University of Manchester, United Kingdom.

[114] Salum, T.F.C., Villeneuve, P., Barea, B., Yamamoto, C.I., Cocco, L.C., Mitchell, D.A., Krieger, N., 2010. Synthesis of biodiesel in column fixed-bed bioreactor using the fermented solid produced by Burkholderia cepacia LTEB11. Process Biochem. 45(8), 13481354.

[115] Sandhya, C., Sumantha, A., Szakacs, G., Pandey, A., 2005. Comparative evaluation of neutral protease production by Aspergillus oryzae in submerged and solid-state fermentation. Process Biochem. 40(8), 2689-2694.

[116] Saqib, A.A.N., Hassan, M., Khan, N.F., Baig, S., 2010. Thermostability of crude endoglucanase from Aspergillus fumigatus grown under solid state fermentation (SSF) and submerged fermentation (SmF). Process Biochem. 45(5), 641-646.

[117] Shen, T., Wang, C., Yang, H., Deng, Z., Wang, S., Shen, B., Shen, Q., 2016. Identification, solid state fermentation and biocontrol effects of Streptomyces hygroscopicus B04 on strawberry root rot. Appl. Soil Ecol. 103, 36-43.

[118] Shih, I.L., Kuo, C.Y., Hsieh, F.C., Kao, S.S., Hsieh, C., 2008. Use of surface response methodology to optimize culture conditions for iturin A production by Bacillus subtilis in solid-state fermentation. $\mathrm{J}$. Chin. Ins. Chem. Eng. 39(6), 635-643.

[119] Shojaosadati, S.A., Babaeipour, V., 2002. Citric acid production from apple pomace in multi-layer packed bed solid-state bioreactor. Process Biochem. 37(8), 909-914.

[120] Sonnenberg, A., Baars, J., Hendricks, P., 2009. IEA Bioenergy Task 42 Biorefinery.

[121] Stabnikova, O., Eang, J.Y., Ivano, V., 2010. Value-added biotechnological Products from organic wastes. In: Wang, L.K., Ivanor, V., Tay, J.H., Hung, Y.T. (Eds.), Handbook of Environmental Engineering, Vol. 10: Environmental Biotechnology. Springer Science + Business Media, pp. 343-388.

[122] Stylist. 23 February 2011; Issue 66, pp. 39-42.

[123] Sun, Z., Li, M., Qi, Q., Gao, C., Lin, C.S.K., 2014. Mixed food waste as renewable feedstock in succinic acid fermentation. Appl. Biochem. Biotechnol. 174(5), 1822-1833.

[124] Suryanarayan, S., 2003. Current industrial practice in solid state fermentations for secondary metabolite production: the Biocon India experience. Biochem. Eng. J. 13(2-3), 189-195.

[125] Takashi, A., Yuan, G.J., Shinji, M., Mohammad Shahedur, R., Kasumasa, O., Makoto, S., 2009. Solid state fermentation of lipopeptide antibiotic iturin A by using a novel solid state fermentation reactor system. J. Environ. Sci. 21, S162-S165.

[126] Tellez-Jurado, A., Arana-Cuenca, A., Becerra, G.A.E., ViniegraGonzalez, G., Loera, O., 2006. Expression of a heterologous laccase by Aspergillus niger cultured by solid-state and submerged fermentations. Enzyme Microb. Technol. 38(5), 665-669.

[127] Thomas, L., Larroche, C., Pandey, A., 2013. Current developments in solid-state fermentation. Biochem. Eng. J. 81, 146-161.

[128] Tokiwa, Y., Calabia, B.P., 2008. Biological production of functional chemicals from renewable resources. Can. J. Chem. 86(6), 548-555.

[129] Turon, X., Venus, J., Arshadi, M., Koutinas, M., Lin, C.S.K., Koutinas, A., 2014. Food waste and byproduct volarization through bio-processing: opportunities and challenges. BioResources. 9(4), $5774-5777$.

[130] Vasquez, J.A., Caprioni, R., Nogueira, M., Menduina, A., Ramos, P., Perez-Martin, R.I., 2016. Valorization of effluents obtained from chemical and enzymatic chitin production of Illex argentines pen byproducts as nutrient supplements for various bacterial fermentations. Biochem. Eng. J. 116, 34-44.

[131] Viniegra-Gonzalez, G., 1997. Solid state fermentation: definition, characteristics, limitations and monitoring. In: Roussos, S., Lonsane, 
B.K., Raimbault, M., Viniegraz-Gonzalez, G. (Eds.), Advances in Solid State Fermentation. Kluwer Academic Publishers, Dordrecht, pp. 5-22.

[132] Wang, H., Chen, H., 2016. Clavulanic acid production by Streptomyces clavuligerus using solid state fermentation on polyurethane foam. Trends Renew. Energy. 2(1), 2-12.

[133] Bradley, D., 2007. Plastics, naturally. Science in School. 5, 66-69.

[134] Webb, C., Koutinas, A.A., Wang, R.H., 2005. Developing a sustainable bioprocessing strategy based on a generic feedstock. In: Scheper, T., Zhong, J.J., (Eds.), Biomanufacturing Advance in Biochem Eng/Biotechnology. Springer-Verlag Berlin, 87, 195-268.

[135] Wolski, E., Menusi, E., Remonatto, D., Vardanega, R., Arbter, F., Rigo, E., Ninow, J., Mazutti, M.A., Di Luccio, M., de Oliveira, D., Treichel, H., 2009. Partial characterization of lipases produced by a newly isolated Penicillium sp. in solid state and submerged fermentation: A comparative study. LWT Food Sci. Technol. 42(9), 1557-1560.

[136] Xu, Y., Wang, R.H., Koutinas, A.A., Webb, C., 2010. Microbial biodegradable plastic production from a wheat-based biorefining strategy. Process Biochem. 45(2), 153-163.
[137] Yang, H., Li, J., Du, G., Liu, L., 2017. Microbial production and molecular engineering of industrial enzymes: challenges and strategies. In: Brahmachari, G., Demian, A.L., Adrio, J. (Eds.), Biotechnology of Microbial Enzymes - Production, Biocatalysis and Industrial Applications. Academic Press, pp. 151-165.

[138] Yazid, N.A., Barrena, R., Komilis, D., Sanchez, A., 2017. Solid-state fermentation as a novel paradigm for organic waste valorization: a review. Sustainability. 9(2), 1-28.

[139] Yoon, L., Ang, T.N., Ngoh, G.C., Chua, A.S.M., 2014. Fungal solidstate fermentation and various methods of enhancement in cellulose production. Biomass Bioenergy. 67, 319-338.

[140] Zhang, B.B., Lu, L.P., Xu, G.R., 2015. Why solid-state fermentation is more advantageous over submerged fermentation for converting high concentration of glycerol into Monacolin K by Monascus purpureus 9901: a mechanistic study. J. Biotechnol. 2016, 6-65.

[141] Zhong-Tao, S., Lin-Mao, T., Cheng, L., Jin-Hua, D., 2009. Bioconversion of apple pomace into multienzyme bio-feed by two mixed strains of Aspergillus niger in solid state fermentation. Electronic J. Biotechnol. 12(1), 3-13. 